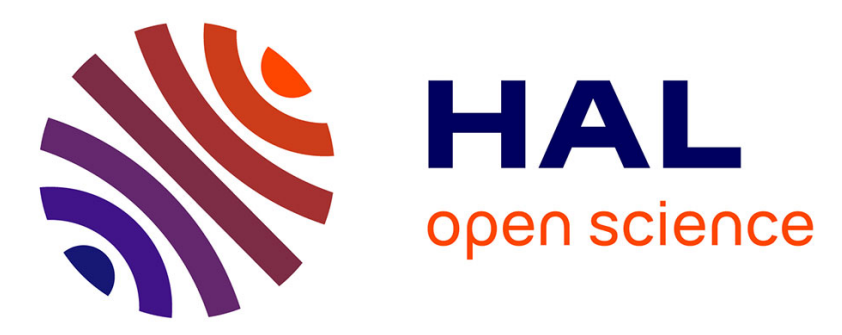

\title{
Three-phenyl transfer in palladium-catalyzed C-C coupling reactions by triarylbismuths: A mechanistic study
}

Pricilia Kutudila, Roberto Linguerri, Miguel Ponce-Vargas, Christophe Pichon, Sylvie Condon, Majdi Hochlaf

\section{To cite this version:}

Pricilia Kutudila, Roberto Linguerri, Miguel Ponce-Vargas, Christophe Pichon, Sylvie Condon, et al.. Three-phenyl transfer in palladium-catalyzed C-C coupling reactions by triarylbismuths: A mechanistic study. Molecular Catalysis, 2020, 482, 7p. 10.1016/j.mcat.2019.110649 . hal-02429383

\section{HAL Id: hal-02429383 https://hal.science/hal-02429383}

Submitted on 9 Jun 2021

HAL is a multi-disciplinary open access archive for the deposit and dissemination of scientific research documents, whether they are published or not. The documents may come from teaching and research institutions in France or abroad, or from public or private research centers.
L'archive ouverte pluridisciplinaire HAL, est destinée au dépôt et à la diffusion de documents scientifiques de niveau recherche, publiés ou non, émanant des établissements d'enseignement et de recherche français ou étrangers, des laboratoires publics ou privés. 
archives-ouvertes

\section{Three-phenyl transfer in palladium-catalyzed C-C coupling reactions by triarylbismuths: A mechanistic study}

Pricilia Kutudila, Roberto Linguerri, Miguel Ponce-Vargas, Christophe Pichon, Sylvie Condon, Majdi Hochlaf

\section{To cite this version:}

Pricilia Kutudila, Roberto Linguerri, Miguel Ponce-Vargas, Christophe Pichon, Sylvie Condon, et al.. Three-phenyl transfer in palladium-catalyzed C-C coupling reactions by triarylbismuths: A mechanistic study. Molecular Catalysis, 2020, 482, 7p. 10.1016/j.mcat.2019.110649 . hal-02429383

\section{HAL Id: hal-02429383 \\ https://hal.archives-ouvertes.fr/hal-02429383}

Submitted on 9 Jun 2021

HAL is a multi-disciplinary open access archive for the deposit and dissemination of scientific research documents, whether they are published or not. The documents may come from teaching and research institutions in France or abroad, or from public or private research centers.
L'archive ouverte pluridisciplinaire HAL, est destinée au dépôt et à la diffusion de documents scientifiques de niveau recherche, publiés ou non, émanant des établissements d'enseignement et de recherche français ou étrangers, des laboratoires publics ou privés. 


\section{THREE-PHENYL TRANSFER IN PALLADIUM-CATALYZED C-C COUPLING REACTIONS BY TRIARYLBISMUTHS: A MECHANISTIC STUDY}

Pricilia Kutudila, ${ }^{\mathrm{a}, \mathrm{b}}$ Roberto Linguerri, ${ }^{\mathrm{a}}$ Miguel Ponce-Vargas, ${ }^{\mathrm{c}}$ Christophe Pichon, ${ }^{\mathrm{b}}$ Sylvie Condon, ${ }^{\mathrm{b}}$ Majdi Hochlaf, *

${ }^{a}$ Université Paris-Est, Laboratoire Modélisation et Simulation Multi Echelle, MSME UMR 8208 CNRS, 5 bd Descartes, 77454 Marne-la-Vallée, France

${ }^{\mathrm{b}}$ Université Paris-Est, Institut de Chimie et des Matériaux Paris-Est, ICMPE UMR 7182 CNRS, 2-8 rue Henri Dunant - 94320 Thiais, France

${ }^{\mathrm{c}}$ Institut de Chimie Moléculaire de Reims, CNRS UMR 7312, Université de Reims Champagne-Ardenne, BP 1039, 51687 Reims, France

KEYWORDS: Triarylbismuth, cross-coupling, density functional calculations, palladium catalysis.

\section{Corresponding Author \\ * Majdi Hochlaf \\ e-mail: hochlaf@univ-mlv.fr}

ORCID

Majdi Hochlaf: 0000-0002-4737-7978 


\section{ABSTRACT}

The unusual reactivity of organobismuth compounds in cross-coupling processes, where they act as multi-aryl sources, opens up new and exciting possibilities in the field of organic synthesis. In particular, the high reactivity of arylbismuths in multifold couplings with arylhalides suggests that three catalytic cycles occur simultaneously. Here, we carry out a computational investigation of a crosscoupling model reaction between bromobenzene $(\mathrm{Ph}-\mathrm{Br})$ and triphenylbismuthine $\left(\mathrm{Ph}_{3} \mathrm{Bi}\right)$, catalyzed by $\operatorname{Pd}(0)$. The energetic profile evidences the exergonic behavior of the overall reaction with a $\Delta_{\mathrm{r}} \mathrm{G}$ of -38.2 kcal.mol ${ }^{-1}$, in good agreement with the experimental results. Moreover, the largest activation energy (39.8 kcal.mol $\left.{ }^{-1}\right)$ is found for the first $\mathrm{Ph}_{3} \mathrm{Bi}$ aryl transfer $\left({ }^{\mathrm{Ph}} \mathrm{P}_{1}{ }_{1}^{\mathrm{Ph} 1} \rightarrow{ }^{\mathrm{Ph}} \mathrm{P}_{2}{ }_{2}{ }^{\mathrm{Ph} 1}\right)$, identified as the rate-determining step. Additional dynamical computations on these potential profiles are needed to confirm these findings. We expect this research to allow for a better understanding of organobismuth palladium-catalyzed C-C coupling reactions and organobismuth chemistry in general. 


\section{INTRODUCTION}

Bismuth compounds ${ }^{1}$ find widespread applications in medicine as gastrointestinal agents, ${ }^{2,3}$ anticancer drugs, ${ }^{4,5}$ and antibiotics. ${ }^{6,7}$ In materials science, triphenylbismuth has proven to be an effective contrast medium, ${ }^{8,9,10}$ and $\mathrm{Bi}(\mathrm{III})$ homobimetallic complexes have shown potential as molecular switches. ${ }^{11}$ In SOHIO Process, Bismuth-Molybdenum oxides catalyze the ammonia oxidation of ethylene for the bulky production of acrylonitrile. ${ }^{12}$ Also, under Pd catalysis, triarylbismuth (III) and (V) can be employed as arylating agents. Original researches in C-C coupling reactions refer to the work by Barton $^{13,14}$, Tanaka and Shimada ${ }^{15,16,17}$ and coworkers. General reviews report the versatile use of triarylbismuth in O-, N-, S- and C-arylation, in metal catalysis. ${ }^{18,19,20}$ The elucidation of the mechanisms of palladium-catalyzed cross-coupling reactions has been the object of recent theoretical investigations, like the ones by Meconi et al. ${ }^{21}, \mathrm{Li}$ et al. ${ }^{22}$ and Melvin et al. ${ }^{23}$. Recently, some of us reported the first cross-coupling reaction of $\mathrm{Ar}_{3} \mathrm{Bi}$ with $\mathrm{Ar}^{\prime} \mathrm{X}$ mediated by $\mathrm{Pd}-\mathrm{NHC}$ complexes, where $\mathrm{Ar}_{3} \mathrm{Bi}$ is able to transfer the three aryl moieties. ${ }^{24}$ Indeed, this reaction is occurring at $90^{\circ} \mathrm{C}$ in DMF in the presence of 3 equivalents of PEPPSI Ipr, of $\mathrm{Ph}_{3} \mathrm{Bi}$, of $\mathrm{CsF}$ for $\sim 1 / 3$ equivalent of triaryl bismuth and one equivalent of bromoaryl. Furthermore, these organometallic reagents exhibit light and air moisture-stability, nontoxicity, ease of synthesis, and high functional group tolerance. ${ }^{25}$ Thus, in the context of the development of eco-friendly processes for a sustainable chemistry, triarylbismuths rise as green and atomefficient organometallic coupling reagents.

The unusual reactivity of organobismuth compounds in cross-coupling processes, where they act as multi-aryl sources, opens up exciting possibilities in the field of organic synthesis. The major reactivity of organobismuth derivatives constitutes another appealing feature in comparison to their nitrogen and phosphorus counterparts. We recently conducted a mechanistic study ${ }^{26}$ of the chemoselective reaction between 3-chloro-6-iodopyridazine ${ }^{27}$ and triphenylbismuth, where a simple catalytic cycle has been proposed, comprising the three following steps: (1) the oxidative addition of the catalyst to reagents, (2) the substitution of one halide by an aryl, and (3) the reductive elimination releasing the coupling product and regenerating the catalyst. We found that the oxidative addition corresponds to the rate-determining step. We also demonstrated the reactivity of triarylbismuths as nucleophilic aryl donors in the crosscoupling reactions controlled by the $\operatorname{Pd}(0) / \mathrm{Pd}(\mathrm{II})$ catalytic system. However, these green reagents are distinguished from other nucleophilic organometallic compounds by the transferability of their three aryl moieties, in the context of palladium-catalyzed reactions. Significant differences in terms of reactivity were also noted depending on the substituents of the $\mathrm{Ar}_{3} \mathrm{Bi}$ aromatic rings.

In this paper, we present the results of a computational investigation of the cross-coupling model reaction between bromobenzene $(\mathrm{Ph}-\mathrm{Br})$ and triphenylbismuthine $\left(\mathrm{Ph}_{3} \mathrm{Bi}\right)$, catalyzed by $\mathrm{Pd}(0)$, using density functional theory (DFT) (Scheme 1) and for the whole transformation (Scheme 2). 


$$
\mathrm{Ph}-\mathrm{Br}+\mathrm{Ph}_{3} \mathrm{Bi} \underset{\mathrm{DMF}}{\mathrm{Pd}(0)} \mathrm{Ph}-\mathrm{Ph}+\mathrm{Ph}_{2} \mathrm{BiBr}
$$

Scheme 1. Model C-C coupling reaction of bromobenzene with triphenylbismuth under palladium catalysis.

$$
3 \mathrm{Ph}-\mathrm{Br}+\mathrm{Ph}_{3} \mathrm{Bi} \rightarrow 3 \mathrm{Ph}-\mathrm{Ph}+\mathrm{BiBr}_{3}
$$

Scheme 2. Global reaction for the three-aryl transfer process from $\mathrm{Ph}_{3} \mathrm{Bi}$ to $\mathrm{Ph}-\mathrm{Br}$.

Until now, a mechanism representing the three-aryl transfer has never been suggested. For the whole transformation (Scheme 2) we propose a detailed mechanism consisting of three catalytic cycles, each associated to the transfer of one aryl from $\mathrm{Ph}_{3} \mathrm{Bi}$. Computations allow establishing a new global reaction mechanism in which the organobismuth $\mathrm{Ph}_{2} \mathrm{BiBr}$ generated in situ takes part, in a similar way as $\mathrm{Ph}_{3} \mathrm{Bi}$, in a new catalytic cycle ( $2^{\text {nd }}$ phenyl transfer). This cycle produces the arylbismuth $\mathrm{PhBiBr}_{2}$, able to participate in a subsequent catalytic cycle ( ${ }^{\text {rd }}$ phenyl transfer) giving rise to $\mathrm{BiBr}_{3}$ and $3 \mathrm{Ph}-\mathrm{Ph}$. This multi-step catalytic process reflects the fact that experimentally the reaction requires 3 equivalents of halogenated derivative for 1 equivalent of triarylbismuth, and, therefore, the transferability of the three aryls, provided that the energetics of the three catalytic cycles are of the same order. We conduct this mechanistic study through DFT methodologies to determine also the rate-limiting step of this palladiumcatalyzed C-C coupling reaction. We consider the Polarizable Continuum Model (PCM) in order to reproduce the solvation effects of dimethylformamide (DMF), in line with the experiment. In PCM, the solvent is represented by a polarizable continuum medium characterized by its dielectric permittivity $\mathcal{E}$ and other macroscopic parameters. ${ }^{28,29}$

\section{COMPUTATIONAL DETAILS}

All DFT calculations were performed by using the Gaussian 09 quantum chemistry package. ${ }^{30}$ The PBE0 non-empirical GGA-based functional ${ }^{31,32,33}$ was employed in conjunction with Dunning's ccpVTZ basis set. ${ }^{34,35,36,37,38}$ For Br (ECP10MDF), Pd (ECP28MDF) and Bi (ECP60MDF) relativistic effective core potentials have been considered. No symmetry constraints $\left(C_{1}\right.$ point group) were imposed during molecular structure optimizations. Frequency analyses were systematically performed to characterize the optimized structures as minima or transition states. All transition states were further inspected by intrinsic reaction coordinate (IRC) $)^{39,40,41,42}$ calculations to confirm that they connect reactants and products along the corresponding reaction coordinate. The results from these IRC calculations are 
provided as Supporting Information. The evaluation of atomic charges was carried out through a Natural Bond Orbital (NBO 6.0) analysis. ${ }^{43,44,45}$ All structures were fully re-optimized in DMF as solvent using the PCM method. The energies reported in the text correspond to corrected free energies. Thermal corrections were added and computed within the harmonic potential approximation on previously optimized structures at $298 \mathrm{~K}$ and $1 \mathrm{~atm}$ pressure. To take into account the energy contributions from dispersion interactions, empirical corrections were added using the D3 Grimme's approach (GD3), as implemented in Gaussian 09. ${ }^{46}$

In addition, we carried out a Noncovalent Interactions $(\mathrm{NCI})^{47}$ analysis for the three different transition states found for the transmetalation step: ${ }^{\mathrm{Ph}} \mathrm{TS}_{2}{ }^{\mathrm{Ph} 1},{ }^{\mathrm{Ph}} \mathrm{TS}_{2}{ }^{\mathrm{Ph} 2},{ }^{\mathrm{Ph}} \mathrm{TS}_{2}{ }^{\mathrm{Ph} 3}$. This analysis relies on the electron density topology and provides a direct 3D representation of regions where noncovalent interactions arise. The NCI is based on the reduced density gradient plot, $s$ :

$$
s=\frac{1}{2\left(3 \pi^{2}\right)^{1 / 3}} \frac{|\nabla \rho|}{\rho^{4 / 3}}
$$

where $|\nabla \rho|$ corresponds to the norm of the electronic density gradient vector.

\section{RESULTS AND DISCUSSION}

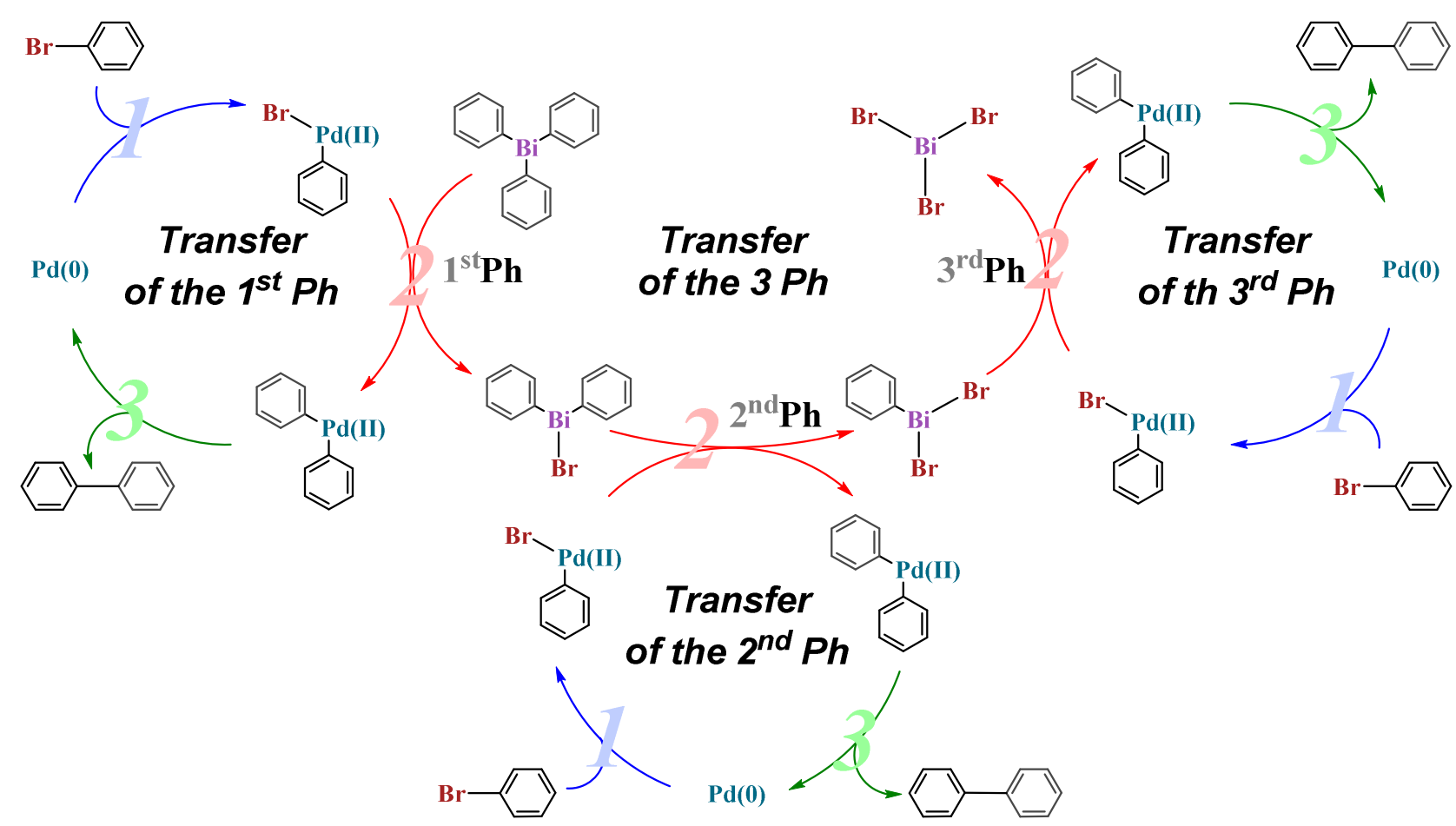

Scheme 3. Catalytic cycles for the three-aryl transfer process. 
A plausible mechanism for the palladium-catalyzed cross-coupling reaction of bromobenzene and triphenylbismuth is presented in Scheme 1. This domino reaction proceeds by means of three catalytic cycles, each one related to phenyl group transfer. In turn, a given catalytic cycle comprises the following steps: (1) oxidative addition, (2) transmetalation, and (3) reductive elimination.

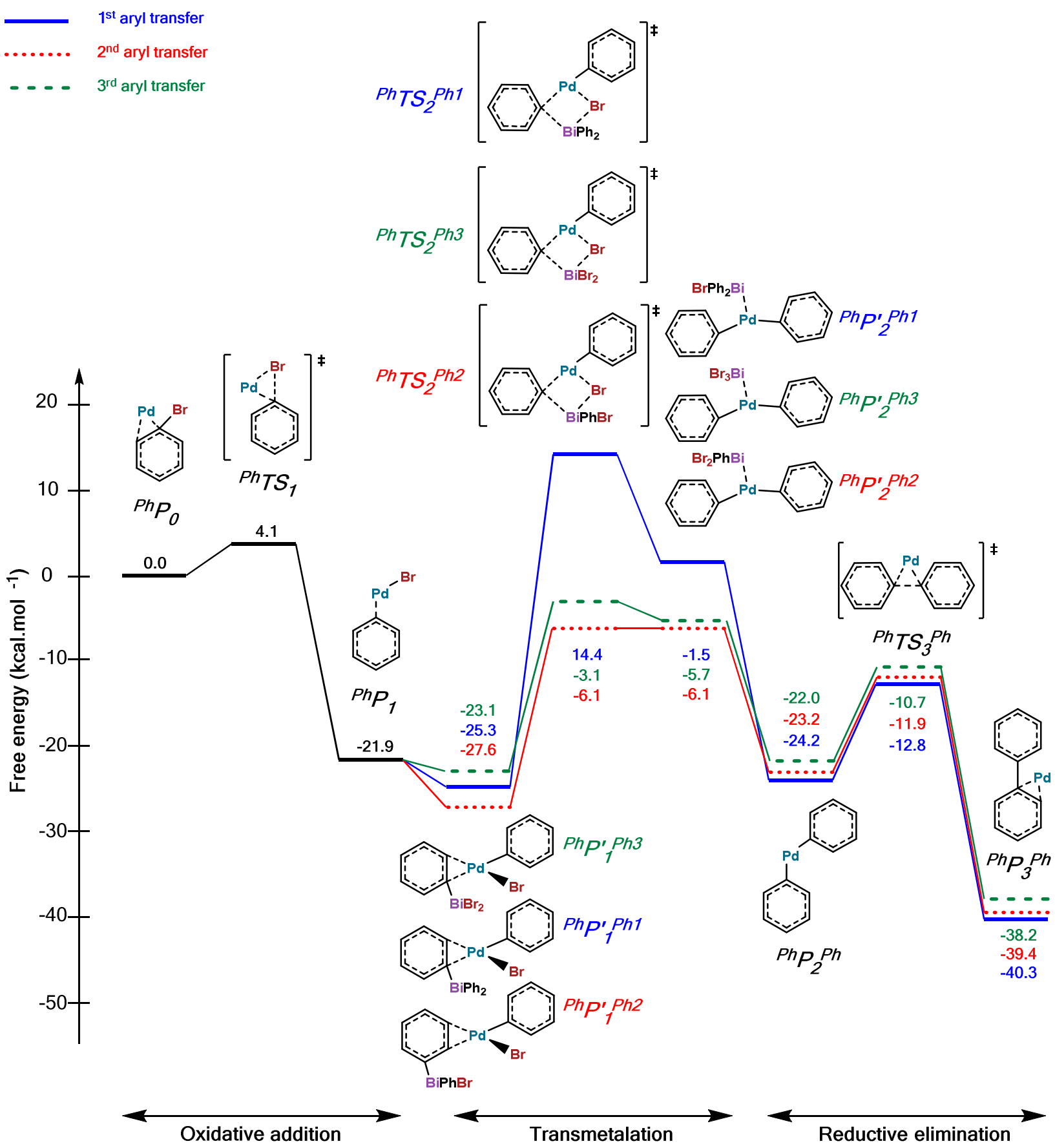


Figure 1: Reaction profile of the palladium-catalyzed aryl transfer reaction. 


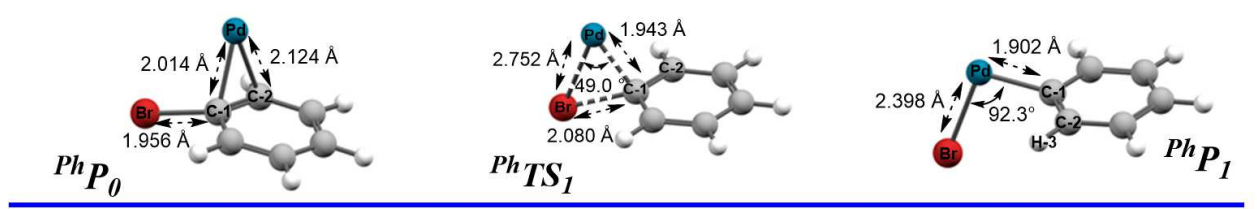

Step 1 - Oxidative addition
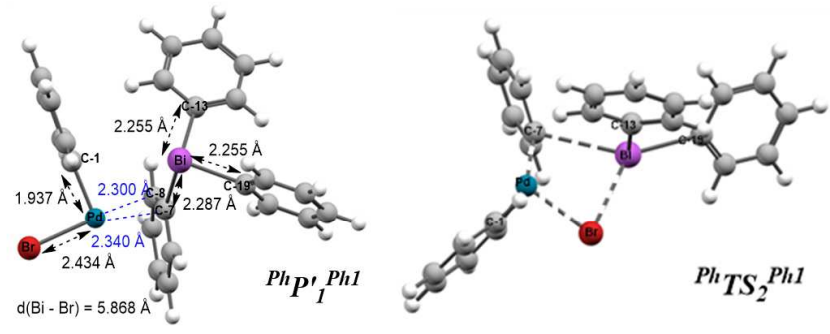

$1^{\text {st }}$ transfer - Step $2^{\text {I }}$ with $\mathrm{Ph}_{\mathbf{3}} \mathrm{Bi}$
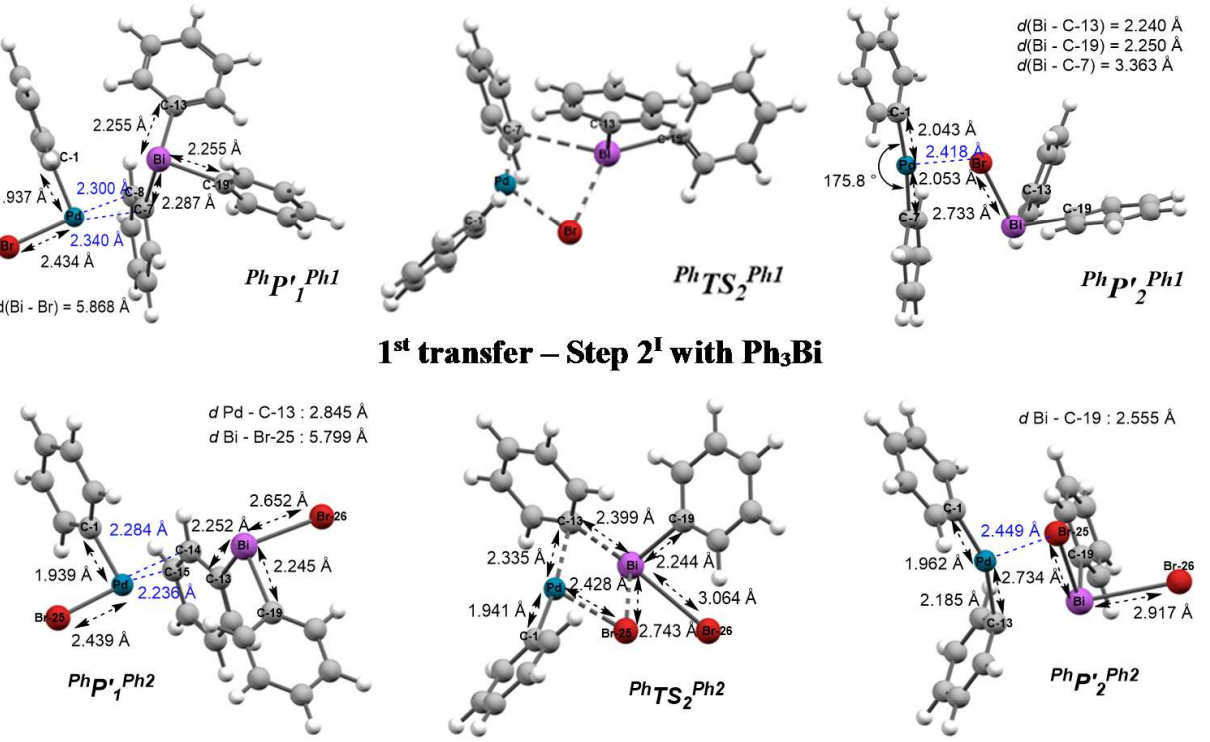

$2^{\text {nd }}$ transfer - Step $2^{\text {II }}$ with $\mathrm{Ph}_{2} \mathrm{BiBr}$
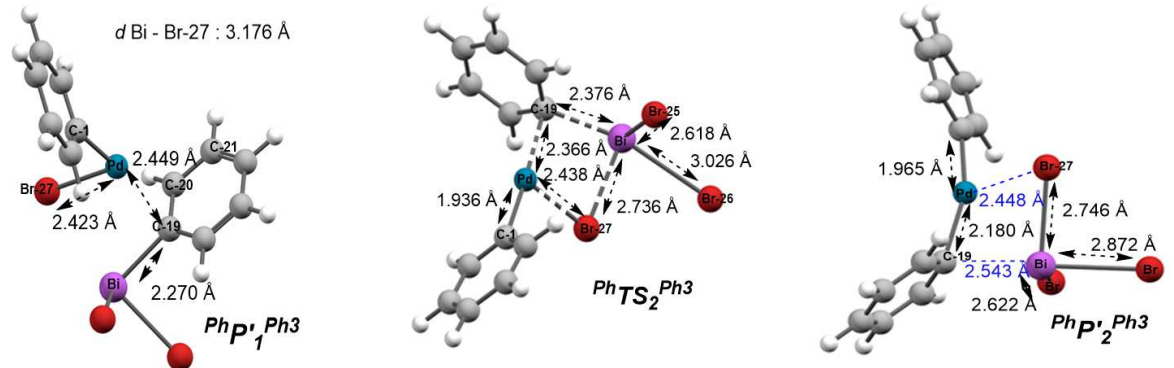

$3^{\text {rd }}$ transfer - Step $2^{\text {III }}$ with $\mathrm{PhBiBr}_{2}$

Step 2 - Transmetalation / Metathesis
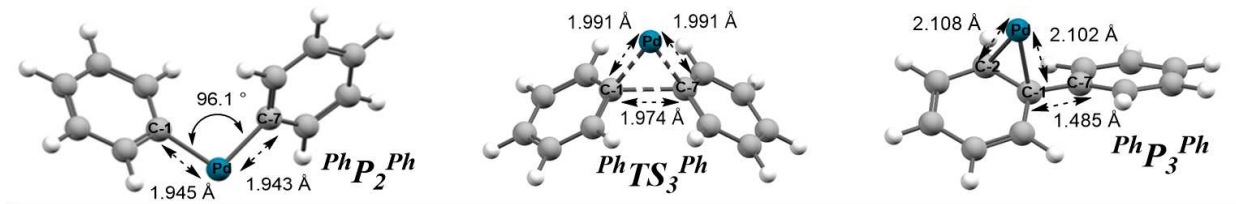

Step 3-Reductive elimination

Figure 2: Optimized structures of the species depicted in Figure 1. We give also the values of selected bond lengths (in $\AA$ ). $\mathrm{Bi}$ is in light violet, $\mathrm{Br}$ in red and Pd in dark turquoise. 
Figure 1 displays the calculated energy profiles for the overall reaction, while Figure 2 depicts the corresponding calculated structures. The intermediary species are labelled as $\mathrm{P}_{\mathrm{i}}$, and the transition states as $\mathrm{TS}_{\mathrm{i}}$ where $\mathrm{i}$ goes from 0 to 3 depending on the number of generated products. With regard to the intermediate species, an apostrophe (') is added to pinpoint that a two-block association occurs from the Pd-halide interaction. Moreover, a right-side index points out the presence of an aromatic fragment originated from the arylbismuth $\left({ }^{\mathrm{Ph} 1}\right.$ from $\mathrm{Ar}_{3} \mathrm{Bi}$, ${ }^{\mathrm{Ph} 2}$ from $\mathrm{Ar}_{2} \mathrm{BiX}$, and ${ }^{\mathrm{Ph} 3}$ from $\left.\mathrm{ArBiX}_{2}\right)$. For the sake of simplicity, the reaction has been modelled in the absence of any ligands on the palladium catalyst. Thus, no pre-activation of the catalyst is considered.

Globally, the shapes of the different energy profiles according to the order of the aryl transfer and the structures of the intermediate and transition state are very similar. The energetic profile of the reaction evidences the exergonic behavior of the overall reaction $\left({ }^{\mathrm{Ph}} \mathrm{P}_{0} \rightarrow{ }^{\mathrm{Ph}} \mathrm{P}_{3}{ }^{\mathrm{Ph}}\right)$ with a free energy difference $\left(\Delta_{\mathrm{r}} \mathrm{G}\right)$ of about $-39 \mathrm{kcal}^{\mathrm{mol}} \mathrm{m}^{-1}$ (at $298 \mathrm{~K}$ in DMF with GD3 correction), supporting the spontaneous nature of the reaction in good agreement with the experimental results. The overall reaction is thermodynamically favorable, irrespective of the organobismuth species involved $\left(\mathrm{Ph}_{3} \mathrm{Bi}, \mathrm{Ph}_{2} \mathrm{BiBr}\right.$ and $\left.\mathrm{PhBiBr}_{2}\right)$. The highest activation energy $\left(39.7 \mathrm{kcal} \mathrm{mol}^{-1}\right)$ is found in the transmetalation stage of the first phenyl group transfer $\left({ }^{\mathrm{Ph}} \mathrm{P}_{1}{ }_{1}^{\mathrm{Ph} 1} \rightarrow{ }^{\mathrm{Ph}} \mathrm{P}_{2}{ }_{2}^{\mathrm{Ph} 1}\right)$.

Each catalytic cycle starts with the ligand-free $\mathrm{Pd}(0)$ insertion in the $\mathrm{C}-\mathrm{Br}$ bond of bromobenzene, leading to ${ }^{\mathrm{Ph}} \mathrm{P}_{1}$ via the transition state ${ }^{\mathrm{Ph}} \mathrm{TS}_{1}$. The starting reactant ${ }^{\mathrm{Ph}} \mathrm{P}_{0}$ (Figure 2) taken as reference in the energetic profiles corresponds to a complex formed with $\operatorname{Pd}(0)$ and the bromide derivative. The palladium atom is coordinated to carbons $\mathrm{C}-1$ and $\mathrm{C}-2$ of the aromatic ring in a $\eta^{2}$ complex, where the bond lengths are 2.014 $\AA$ and $2.124 \AA$, respectively. ${ }^{\mathrm{Ph}} \mathrm{P}_{0}$ evolves toward the transition state ${ }^{\mathrm{Ph}} \mathrm{TS}_{1}$ featuring a threemembered ring formed by $\mathrm{Pd}, \mathrm{Br}$ and $\mathrm{C}$ (Figure 2). The subsequent cleavage of the $\mathrm{C}-\mathrm{Br}$ bond and the formation of $\mathrm{Pd}-\mathrm{Br}$ and $\mathrm{Pd}-\mathrm{C}$ bonds result in the stabilized complex ${ }^{\mathrm{Ph}} \mathrm{P}_{1}$. This stage $\left({ }^{\mathrm{Ph}} \mathrm{P}_{0} \rightarrow{ }^{\mathrm{Ph}} \mathrm{P}_{1}\right)$ is exothermic with a free energy variation of $21.9 \mathrm{kcal} \mathrm{mol}^{-1}$ (Figure 1). A NBO analysis confirms the stabilization of the ${ }^{\mathrm{Ph}} \mathrm{P}_{1}$ intermediate with respect to ${ }^{\mathrm{Ph}} \mathrm{P}_{0}$, because of the $\mathrm{Pd}-\mathrm{C} 1$ and $\mathrm{Pd}-\mathrm{Br}$ bond formation.

After the oxidative addition described in the previous paragraph and before the reductive elimination, the transmetalation step (or metathesis stage from a metal point of view) takes place. This step is the most important process of cross-coupling reaction involving triarylbismuths. It was clearly 
evidenced in two cross-coupling reactions developed by some of us in our laboratory (Refs. $[18,21])$ that yields in the derived products are higher if electro-donating groups (3-Me, 4-Me, 4-oMe) are present on the arylbismuth moiety rather than electro-withdrawing groups (carbonyl of ketone or ester in meta or para positions). In this case, the organobismuth species provides one substituent to the $\mathrm{Pd}(\mathrm{II})$ complex generated in the oxidative addition step.

After the second transmetalation step, the last stage of the first catalytic cycle is the ciselimination of two ligands surrounding the $\mathrm{Pd}$ atom, allowing the $\mathrm{C}-\mathrm{C}$ bond formation and the regeneration of the Pd active species via the $\mathrm{Pd}(\mathrm{II})$ reduction to $\mathrm{Pd}(0)$. According to the $\mathrm{IRC}$ calculations, the two carbons linked to the $\mathrm{Pd}$ atom of the intermediate ${ }^{\mathrm{Ph}} \mathrm{P}_{2}^{\mathrm{Ph}}$ get closer, leading to the symmetric threemembered ring transition state ${ }^{\mathrm{Ph}} \mathrm{TS}_{3}{ }^{\mathrm{Ph}}$ (Figure 2). The activation energy associated with this stage is 11.4 kcal.mol ${ }^{-1}$ (Figure 1). Afterwards, the active catalyst $\mathrm{Pd}(0)$ is recovered via the last intermediate ${ }^{\mathrm{Ph}} \mathrm{P}_{3}{ }^{\mathrm{Ph}}$, corresponding to a $\eta^{2}$-coordinated palladium complex, where Pd is linked to C-1 and C-2.

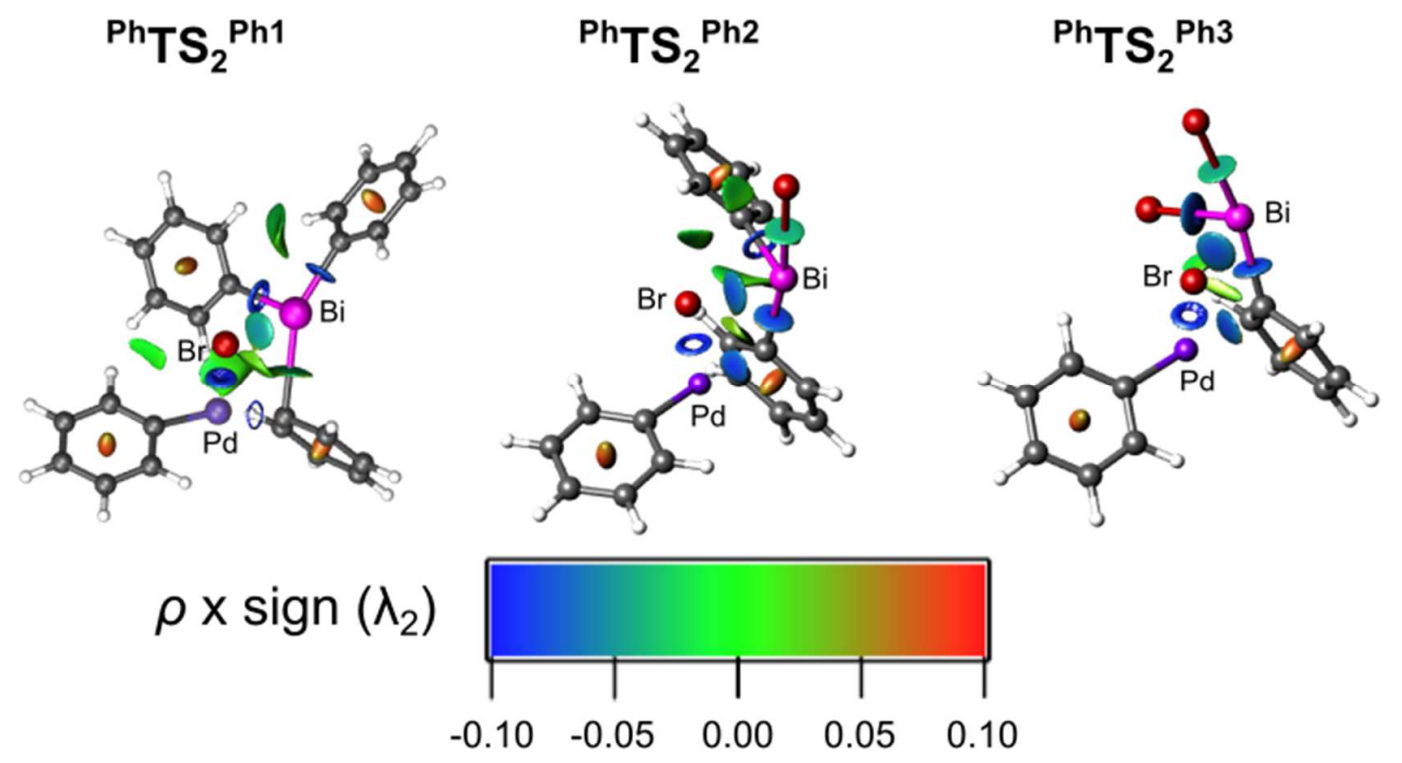

Figure 3: NCI analysis of the three different transition states $\left({ }^{\mathrm{Ph}} \mathrm{TS}_{2}{ }^{\mathrm{Ph} 1},{ }^{\mathrm{Ph}} \mathrm{TS}_{2}{ }^{\mathrm{Ph} 2},{ }^{\mathrm{Ph}} \mathrm{TS}_{2}{ }^{\mathrm{Ph} 3}\right)$ found for the transmetalation step. $\lambda_{2}$ is the second eigenvalue of the electronic density Hessian matrix. Stabilizing forces are characterized by $\lambda_{2}<0$, steric repulsion by $\lambda_{2}>0$, and London interactions by $\lambda_{2} \approx 0$. Color code: blue corresponds to strongly attractive interactions, red to repulsive effects, and green to weak dispersion forces. 
In the following, let's consider the successive phenyl transfers separately to highlight the specificities of each transfer:

First aryl transfer: For the first aryl transfer, the transition state ${ }^{\mathrm{Ph}} \mathrm{TS}_{2}{ }^{\mathrm{Ph} 1}$ displays a Pd-C-Bi-Br fourmembered ring (Figure 2). Unexpectedly, the IRC calculations revealed the existence of the intermediate ${ }^{\mathrm{Ph}} \mathrm{P}_{1}{ }_{1}^{\mathrm{Ph} 1}\left(-25.3 \mathrm{kcal} \cdot \mathrm{mol}^{-1}\right)$ connecting ${ }^{\mathrm{Ph}} \mathrm{TS}_{2}{ }^{\mathrm{Ph} 1}$ and ${ }^{\mathrm{Ph}} \mathrm{P}_{1}$, with an energy difference between ${ }^{\mathrm{Ph}} \mathrm{P}_{1}$ to ${ }^{\mathrm{Ph}} \mathrm{P}_{1}{ }_{1}^{\mathrm{Ph} 1}$ of $-3.4 \mathrm{kcal} \cdot \mathrm{mol}^{-1}$. Interestingly, without considering the dispersion energy correction, such energy difference changes significantly $\left(+3.6 \mathrm{kcal}^{\mathrm{mol}}{ }^{-1}\right)$, highlighting the importance of the dispersion effects in the stabilization of ${ }^{\mathrm{Ph}} \mathrm{P}_{1}{ }_{1}^{\mathrm{Ph} 1}$ complex. Also, weak dispersion forces between bromide and bismuth, in ${ }^{\mathrm{Ph}} \mathrm{TS}_{2}{ }^{\mathrm{Ph} 1}$ are revealed by the NCI analysis (see Figure 3) as a green region between such atoms. Additionally, the rise of $\pi$ interactions between the aromatic rings is also suggested by the NCI.

The migration of phenyl and the formation of $\mathrm{C}-\mathrm{Pd}$ and $\mathrm{Bi}-\mathrm{Br}$ bonds occur through an asynchronous concerted mechanism resulting in ${ }^{\mathrm{Ph}} \mathrm{P}_{2}{ }_{2}^{\mathrm{Ph} 1}$ (Figure 2). First, the $\mathrm{C}-\mathrm{Bi}$ bond breaks, causing the phenyl group transfer (C-7) toward $\mathrm{Pd}$. Then, the $\mathrm{Pd}-\mathrm{C}-7$ bond is formed, as well as $\mathrm{Bi}-\mathrm{Br}$ and $\mathrm{Br}-\mathrm{Pd}$. Comparing the geometries of the stable intermediates ${ }^{\mathrm{Ph}} \mathrm{P}_{1}{ }_{1}^{\mathrm{Ph} 1}$ and ${ }^{\mathrm{Ph}} \mathrm{P}_{2}{ }^{\mathrm{Ph} 1}$ (Figure 2), we notice a contraction of the Pd-C-7 bond (from 2.340 to $2.053 \AA$ ), whereas the Bi-C-7 bond increases (from 2.287 to $3.363 \AA$ ). These variations highlight the formation of the $\mathrm{Pd}-\mathrm{C}$ bond and the cleavage of $\mathrm{Bi}-\mathrm{C}$ occurring during this process.

The release of the $\mathrm{Ph}_{2} \mathrm{BiBr}$ molecule leads to a new palladium complex ${ }^{\mathrm{Ph}} \mathrm{P}_{2}{ }^{\mathrm{Ph}}$ (Figure 2), more stable than ${ }^{\mathrm{Ph}} \mathrm{P}_{2}{ }_{2}{ }^{\mathrm{Ph} 1}$ by $22.7 \mathrm{kcal} . \mathrm{mol}^{-1}{ }^{2}\left(2.1 \mathrm{kcal} . \mathrm{mol}^{-1}\right.$ without the correction GD3). The ${ }^{\mathrm{Ph}} \mathrm{P}_{1}{ }_{1}^{\mathrm{Ph} 1} \rightarrow$ ${ }^{\mathrm{Ph}} \mathrm{P}_{2}{ }^{\mathrm{Ph} 1}$ stage is endothermic with a free energy variation of $23.8 \mathrm{kcal}^{\mathrm{mol}}{ }^{-1}$. This step possesses the highest energy barrier of the overall catalytic cycle, with a free energy barrier of $39.7 \mathrm{kcal}^{\mathrm{mol}}{ }^{-1}$ to connect ${ }^{\mathrm{Ph}} \mathrm{P}_{1}{ }_{1}^{\mathrm{Ph} 1}$ and ${ }^{\mathrm{Ph}} \mathrm{TS}_{2}{ }^{\mathrm{Ph} 1}$ (Figure 1). According to the NCI analysis (Figure 3), the lower stability of the ${ }^{\mathrm{Ph}} \mathrm{TS}_{2}{ }^{\mathrm{Ph} 1}$ transition state can be attributed to the weaker London forces between $\mathrm{Bi}$ and $\mathrm{Br}$ compared to ${ }^{\mathrm{Ph}} \mathrm{TS}_{2}{ }^{\mathrm{Ph} 2}$ (second cycle) and ${ }^{\mathrm{Ph}} \mathrm{TS}_{2}{ }^{\mathrm{Ph} 3}$ (third cycle), where the observed blue regions between $\mathrm{Bi}$ and $\mathrm{Br}$ suggest stronger interactions. Moreover, the $\pi$-interactions between the aromatic rings suggest a more strained and destabilized structure for ${ }^{\mathrm{Ph}} \mathrm{TS}_{2}{ }^{\mathrm{Ph} 1}$. Hence, given the higher energy of ${ }^{\mathrm{Ph}} \mathrm{TS}_{2}{ }^{\mathrm{Ph} 1}$ we can consider ${ }^{\mathrm{Ph}} \mathrm{P}_{1}{ }_{1}^{\mathrm{Ph} 1} \rightarrow{ }^{\mathrm{Ph}} \mathrm{P}_{2}{ }_{2}{ }^{\mathrm{Ph} 1}$ as the rate-limiting step of the overall reaction mechanism. Despite the rather large activation barrier of around $40 \mathrm{kcal}^{\mathrm{mol}}{ }^{-1}$ calculated for the transmetalation process involving the ${ }^{\mathrm{Ph}} \mathrm{P}_{1}{ }_{1}^{\mathrm{Phl}}$ intermediate (rate-limiting step), the overall energy barrier for the first aryl transfer is of only 14 $\mathrm{kcal} \mathrm{mol}^{-1}$, which means that this process will be reasonably fast even at moderate temperature $\left(\sim 100{ }^{\circ} \mathrm{C}\right.$ 
or less). This finding is supported by our previous experimental results, showing that a three-aryl transfer in similar cross-coupling reactions can be easily carried out at temperatures of less than $100{ }^{\circ} \mathrm{C}$, under proper conditions (see Ref. [24]). On the other hand, previous works showed that dynamical effects should be considered as well. For instance, for the $\mathrm{F}^{-}+\mathrm{CH}_{3} \mathrm{Cl} \mathrm{S}_{\mathrm{N}} 2$ reaction, quantum effects may favor high barrier pathways. ${ }^{48}$ Also, the combined experimental, DFT and dynamical computational work by Zheng et al. ${ }^{49}$, a mechanistic study of Pictet-Spengler reactions, revealed that the stereochemical outcomes of this reaction might be complicated by dynamical effects going beyond traditional transition state theory.

Second aryl transfer: In this step, the ligand transfer involves a molecule of $\mathrm{Ph}_{2} \mathrm{BiBr}$. Conventionally, the transition state ${ }^{\mathrm{Ph}} \mathrm{TS}_{2}{ }^{\mathrm{Ph} 2}$ (Figure 2) corresponds to a Pd-C-Bi-Br four-membered ring, where the bismuth atom adopts a seesaw geometry, with $\mathrm{Br}-25$ and $\mathrm{C}-19$ at the base. Again, a stable intermediate ${ }^{\mathrm{Ph}} \mathrm{P}_{1}{ }_{1}^{\mathrm{Ph} 2}$, similar to ${ }^{\mathrm{Ph}} \mathrm{P}_{1}{ }_{1}{ }^{\mathrm{Ph} 1}$ is formed. However, in this case, the $\eta^{2}$ complex is generated between $\mathrm{Pd}$ and the two aromatic phenyl carbons $\mathrm{C}-14$ and $\mathrm{C}-15$, placed in ortho and meta positions with respect to $\mathrm{Bi}$, while in the case of ${ }^{\mathrm{Ph}} \mathrm{P}_{1}{ }_{1}^{\mathrm{Ph} 1}$ complex, the carbons $\mathrm{C}-7$ and $\mathrm{C}-8$ occupy the ipso and ortho positions of $\mathrm{Bi}$, respectively, resulting in more pronounced steric effects. Then ${ }^{\mathrm{Ph}} \mathrm{P}_{1}{ }_{1}^{\mathrm{Ph} 2}$ evolves to ${ }^{\mathrm{Ph}} \mathrm{TS}_{2}{ }^{\mathrm{Ph} 2}$, where the BiBr-25 bond distance decreases from $5.799 \AA$ to $2.734 \AA$. Remarkably, this process requires an activation energy of $21.5 \mathrm{kcal}^{\mathrm{mol}}{ }^{-1}$, about half the energy of the first transfer (Figure 1). The stage ends with the generation of the ${ }^{\mathrm{Ph}} \mathrm{P}_{2}{ }_{2}^{\mathrm{Ph} 2}$ complex resulting from the concerted migration of the phenyl and the formation of the Bi-Br-25 bond.

The comparison between ${ }^{\mathrm{Ph}} \mathrm{P}_{1}{ }_{1}^{\mathrm{Ph} 2}$ and ${ }^{\mathrm{Ph}} \mathrm{P}_{2}{ }_{2}^{\mathrm{Ph} 2}$ intermediates reveals a shortening of the Pd-C-13 distance in the latter (from 2.845 to $2.185 \AA$ ), as well as a stretching of the Bi-C-19 (from 2.245 to 2.555 $\AA$ ) and Pd-Br-25 (from 2.439 to $2.449 \AA$ ) bonds (Figure 2). Afterwards, the ${ }^{\mathrm{Ph}} \mathrm{P}_{2}{ }_{2}^{\mathrm{Ph} 2}$ complex turns into the most stabilized ${ }^{\mathrm{Ph}} \mathrm{P}_{2}{ }^{\mathrm{Ph}}$ complex $\left(17.1 \mathrm{kcal}^{\mathrm{mol}}{ }^{-1}\right)$. This stage is also characterized by the release of $\mathrm{PhBiBr}_{2}$, which can then take part in a new metathesis step of the catalytic cycle.

Third aryl transfer: The last transmetallation process with $\mathrm{PhBiBr}_{2}$ as aryl source is very similar to the previous one. First, according to the IRC study, the process is initiated by a palladium 
tetracoordinated ${ }^{\mathrm{Ph}} \mathrm{P}_{1}{ }_{1}^{\mathrm{Ph} 3}$ complex (Figure 2) obtained after ${ }^{\mathrm{Ph}} \mathrm{P}_{1}$ approaches to the phenyl group of $\mathrm{PhBiBr}_{2}$. There, a complex is formed between $\mathrm{Pd}$ and $\mathrm{C}-20$ and $\mathrm{C}-21$, in ortho and meta positions, respectively. The reaction evolves towards the intermediate ${ }^{\mathrm{Ph}} \mathrm{P}_{2}{ }_{2}^{\mathrm{Ph} 3}$ (Figure 2) via the transition state ${ }^{\mathrm{Ph}} \mathrm{TS}_{2}{ }^{\mathrm{Ph} 3}$. Remarkably, the NCI analysis (Figure 3) reveals that noncovalent forces between Pd and the near Bi are more intense in ${ }^{\mathrm{Ph}} \mathrm{TS}_{2}{ }^{\mathrm{Ph} 3}$ and ${ }^{\mathrm{Ph}} \mathrm{TS}_{2}{ }^{\mathrm{Ph} 2}$ in comparison to ${ }^{\mathrm{Ph}} \mathrm{TS}_{2}{ }^{\mathrm{Ph} 1}$, which results in lower energy assemblies (see Figure 1), in line with the calculated energies. This can be attributed to the shorter distance between the fragments as well as the absence of $\pi$ interactions. Additionally, the $\mathrm{BiBr}_{3}$ release evidences the total consumption of the three aryl moieties, leading to the ${ }^{\mathrm{Ph}} \mathrm{P}_{2}{ }^{\mathrm{Ph}}$ intermediate, more stable than ${ }^{\mathrm{Ph}} \mathrm{P}_{2}{ }_{2}^{\mathrm{Ph} 3}$ by $16.3 \mathrm{kcal} . \mathrm{mol}^{-1}$ (Figure 1). The activation barrier for the last aryl transfer is similar to that for the second one, i.e., about $20.0 \mathrm{kcal} . \mathrm{mol}^{-1}$.

\section{CONCLUDING REMARKS}

The role played by triarylbismuths as classic organometallic nucleophiles in palladium-catalyzed cross-coupling reactions is highlighted in this work. The three stages of this reaction, oxidative addition, metathesis and reductive elimination, have been examined. The metathesis is identified as the ratelimiting step of this process and the only one involving $\mathrm{Ph}_{3} \mathrm{Bi}$. On the other hand, the calculated $\Delta_{\mathrm{r}} \mathrm{Gs}$ reveal that the overall process is thermodynamically favorable. The energetic profile evidences the exergonic behavior of the overall reaction, i.e. involving the three-aryl transfer $\left({ }^{\mathrm{Ph}} \mathrm{P}_{0} \rightarrow{ }^{\mathrm{Ph}} \mathrm{P}_{3}{ }^{\mathrm{Ph}}\right)$, with a calculated $\Delta_{\mathrm{r}} \mathrm{G}$ of $-38.2 \mathrm{kcal}^{\mathrm{mol}}{ }^{-1}$, supporting the spontaneous nature of the process in good agreement with the experimental results.

The oxidative addition and the reductive elimination involve the same intermediates and transition states $\left({ }^{\mathrm{Ph}} \mathrm{TS}_{1}\right.$ and $\left.{ }^{\mathrm{Ph}} \mathrm{TS}_{3}{ }^{\mathrm{Ph}}\right)$. The activation energies of these steps do not change significantly in the three cases studied. Regarding the second step, the highest activation energy $\left(39.8 \mathrm{kcal}^{-\mathrm{mol}^{-1}}\right)$ is found in the first aryl transfer with $\mathrm{Ph}_{3} \mathrm{Bi}\left({ }^{\mathrm{Ph}} \mathrm{P}_{1}{ }_{1}^{\mathrm{Ph} 1} \rightarrow{ }^{\mathrm{Ph}} \mathrm{P}{ }_{2}{ }^{\mathrm{Ph} 1}\right)$, which enables us to identify it as the rate-limiting stage, followed by the second $\left(21.5 \mathrm{kcal} . \mathrm{mol}^{-1}\right)$ and third one $\left(20.0 \mathrm{kcal}^{\mathrm{mol}} \mathrm{l}^{-1}\right)$. Note that dynmical and quantum effect may participate and lead to an effective acceleration of the reaction?? TO BE SAID BETTER. The NCI analysis reveals that noncovalent forces between Pd and the near Bi are more intense in ${ }^{\mathrm{Ph}} \mathrm{TS}_{2}{ }^{\mathrm{Ph} 3}$ and ${ }^{\mathrm{Ph}} \mathrm{TS}_{2}{ }^{\mathrm{Ph} 2}$ than in ${ }^{\mathrm{Ph}} \mathrm{TS}_{2}{ }^{\mathrm{Ph} 1}$, resulting in lower energy assemblies, in good agreement with the calculated energies.

\section{ASSOCIATED CONTENT}


Supporting Information describes the IRC results. 


\section{REFERENCES}

[1] Suzuki, H.; Matano, H. Organobismuth Chemistry; Elsevier Science, Amsterdam, 2001.

[2] Gorbach, S. L. Bismuth Therapy in Gastrointestinal Diseases. Gastroenterology. 1990, 99, 863-75.

[3] Baldwin, G. S. Bismuth Ions, Gastrins, and Their Biological Activity in the Gastrointestinal Tract, Advances in Medicine and Biology; Berhardt, L. V.; Nova Sciences, New York, 2017; pp 131-145.

[4] Tiekink, E. R. Antimony and Bismuth Compounds in Oncology. Critical Rev. Oncology/Hematology 2002, 42, 217-224

[5] Cui, L.; Bi, C.; Fan, Y.; Li, X.; Meng, X.; Zhang, N.; Zhang, Z. Synthesis, crystal structures, DNA interaction and anticancer activity of organobismuth(V) complexes. Inorg. Chim. Acta 2015, 437, 41-46.

[6] Pathak, A.; Blair, V. L.; Ferrero, R. L.; Mehring, M.; Andrews, P. C. Bismuth(III) benzohydroxamates: powerful anti-bacterial activity against Helicobacter pylori and hydrolysis to a unique $\mathrm{Bi}_{34}$ oxido-cluster $\left[\mathrm{Bi}_{34} \mathrm{O}_{22}(\mathrm{BHA})_{22}(H \text {-BHA })_{14}(\mathrm{DMSO})_{6}\right]$ Chem. Commun. 2014, 50, 1523215234; and references cited therein.

[7] Kotani, T.; Nagai, D.; Asahi, K.; Suzuki, H.; Yamao, F.; Kataoka, N.; Yagura, T. Antibacterial properties of some cyclic organobismuth(III) compounds. Antimicrob. Agents Chemother 2005, 49, 2729 2734.

[8] Deb, S.; Abdulghani, S.; Behiri, J. C. Radiopacity in Bone Cements using an Organo-bismuth Compound Biomaterials 2002, 23, 3387-3393.

[9] Xu, H.; Abdulghani, S.; Behiri, J.; Sabokbar, A. Osteolytic potential of triphenyl bismuth as an alternative contrast medium in acrylic bone cement. J. Biomed. Mater. Res. B. Appl. Biomater. 2005, 75, 64-73.

[10] Delaviz, Y.; Zhang, Z.-X.; Cabasso, I.; Smid, J. Homogeneous Radiopaque Polymers with Organobismuth Compounds. J. Appl. Polym. Sci. 1990, 40, 835-843.

[11] Najjari, B.; Le Gac, S.; Roisnel, T.; Dorcet, V.; Boitrel, B. Metal Migration Processes in Homo- and Heterobimetallic Bismuth(III)-Lead(II) Porphyrin Complexes: Emergence of Allosteric Newton's Cradlelike Devices. J. Am. Chem. Soc. 2012, 134, 16017-16032.

[12] Hanna, T. A. The Role of Bismuth in the SOHIO Process. Coordination Chemistry Reviews, 2004, $248,429-440$.

[13] Barton, D. H. R.; Ozbalik, N.; Ramesh, M. The Chemistry of Organobismuth Reagents: Part XIII Ligand Coupling induced by $\mathrm{Pd}(0)$. Tetrahedron 1988, 44, 5661-5668.

[14] Abramovitch, R. A.; Barton, D. H. R.; Finet, J.-P. Newer Methods of Arylation. Tetrahedron 1988, 44, 3039-3071.

[15] Rao, M. L. N.; Yamasaki, O.; Shimada, S.; Tanaka, T.; Suzuki, Y.; Tanaka, M. Palladium-Catalyzed Cross-Coupling Reaction of Triarylbismuths with Aryl Halides and Triflates, Org. Lett., 2001, 3, 41034105.

[16] Rao, M. L. N.; Shimada, S.; Tanaka, M. Palladium Complex-Catalyzed Cross-Coupling Reaction of Organobismuth Dialkoxides with Triflates, Org. Lett., 1999, 1, 1271-1273.

[17] Shimada, S.; Yamazaki, O.; Tanaka, T.; Rao, M. L. N.; Suzuki, Y.; Tanaka, M. 5,6,7,12

Tetrahydrodibenz[c,f][1,5]azabismocines: Highly Reactive and Recoverable Organobismuth Reagents for Cross-Coupling Reactions with Aryl Bromides, Angew. Chem. Int. Ed. 2003, 42, 1845 - 1848.

[18] Shimada, S.; Rao, M. L. N. Bismuth-mediated Organic Reactions. Top. Curr. Chem., Ollevier, T.; Springer: Berlin, 2012. pp. 199.

[19] Condon, S.; Pichon, C.; Davi, M. Preparation and Synthetic Applications of Trivalent Arylbismuth Compounds as Arylating Reagents. A Review. Org. Prep. Proced. Int. 2014, 46, 89-131.

[20] Gagnon, A.; Dansereau, J.; Le Roch, A. Organobismuth Reagents: Synthesis, Properties and Applications in Organic Synthesis. Synthesis 2017, 49, 1707-1745. 
[21] Meconi, G. M. ; Vummaleti, S. V. C.; Luque-Urrutia, J. A.; Belanzoni, P.; Nolan, S. P.; Jacobsen, H.; Cavallo, L.; Solà, M.; Poater, A. Mechanism of the Suzuki-Miyaura Cross-Coupling Reaction Mediated by [Pd(NHC)(allyl)Cl] Precatalysts, Organometallics, 2017, 36, 2088-2095.

[22] Li, G.; Lei, P.; Szostak, M.; Casals-Cruañas, E. ; Poater, A.; Cavallo, L.; Nolan, S. P. Mechanistic Study of Suzuki-Miyaura Cross-Coupling Reactions of Amides Mediated by [Pd(NHC)(allyl)Cl] Precatalysts, ChemCatChem, 2018, 10, 3096-3106.

[23] Melvin, P. R.; Nova, A.; Balcells, D.; Hazari, N.; Tilset, M. DFT Investigation of Suzuki-Miyaura Reactions with Aryl Sulfamates Using a Dialkylbiarylphosphine-Ligated Palladium Catalyst, Organometallics, 2017, 36, 3664-3675.

[24] Cassirame, B.; Condon, S.; Pichon, C. Mechanism Insight and Scope of PEPPSI-catalyzed CrossCoupling Reaction between Triarylbismuth and Arylbromide. J. Mol. Catal. A: Chem. 2016, 425, 20652078.

[25] Luan, J.; Zhang, L.; Hu, Z. Synthesis, Properties Characterization and Applications of Various Organobismuth Compounds. Molecules 2011, 16, 4191-4230.

[26] Kutudila, P.; Linguerri, R.; Al-Mogren, M. M.; Pichon, C.; Condon, S.; Hochlaf, M. First Principle Investigations of Organobismuth Palladium-catalyzed $\mathrm{C}-\mathrm{C}$ Coupling Reaction: Mechanism, Chemoselectivity and Solvent Effects. Theor. Chem. Acc. 2016, 135, 1-10.

[27] Urgin, K.; Aubé, C.; Pipelier, M.; Blot, V.; Thobie-Gautier, C.; Sengmany, S.; Lebreton, J.; Léonel, E.; Dubreuil, D.; Condon, S. Pd-Catalyzed Chemoselective Cross-Coupling Reaction of Triaryl- or Triheteroarylbismuth Compounds with 3,6-Dihalopyridazines. Eur. J. Org. Chem. 2013, 117-124.

[28] Tomasi, J.; Mennucci, B.; Cammi, R. Quantum Mechanical Continuum Solvation Models. Chem. Rev. 2005, 105, 2999-3093.

[29] Mennucci, B.; Tomasi, J.; Cammi, R.; Cheeseman, J. R.; Frisch, M. J.; Devlin, F. J.; Gabriel, S.; Stephens, P. J. Polarizable Continuum Model (PCM) Calculations of Solvent Effects on Optical Rotations of Chiral Molecules. J. Phys. Chem. A 2002, 106, 6102-6113.

[30] Gaussian 09. Revision D. 01. Frisch, M. J. et al. Gaussian Inc., Wallingford CT, 2009.

[31] Adamo, C.; Barone, V. Toward Reliable Density Functional Methods without Adjustable Parameters: The PBE0 Model. J. Chem. Phys. 1999, 110, 6158-6170.

[32] Perdew, J. P.; Ernzerhof, M.; Burke, K. Rationale for Mixing Exact Exchange with Density Functional Approximations. J. Chem. Phys. 1996, 105, 9982-9985.

[33] Ernzerhof, M.; Scuseria, G. E. Assessment of the Perdew-Burke-Ernzerhof Exchange-Correlation Functional. J. Chem. Phys. 1999, 110, 5029-5036.

[34] Dunning Jr., T. H. Gaussian Basis Sets for Use in Correlated Molecular Calculations. I. The Atoms Boron through Neon and Hydrogen. J. Chem. Phys. 1989, 90, 1007-1023.

[35] Woon, D. E.; Dunning Jr., T. H. Gaussian Basis Sets for Use in Correlated Molecular Calculations. III. The Atoms Aluminum through Argon. J. Chem. Phys. 1993, 98, 1358-1371.

[36] Peterson, K.A.; Figgen, D.; Dolg, M.; Stoll, H. Energy-Consistent Relativistic Pseudopotentials and Correlation consistent Basis Sets for the 4d Elements Y-Pd. J. Chem. Phys. 2007, 126, 124101-1-12410112.

[37] Peterson, K. A.; Shepler, B. C.; Figgen, D.; Stoll, H. On the Spectroscopic and Thermochemical Properties of ClO, BrO, IO, and their Anions. J. Phys. Chem. A 2006, 110, 13877-13883.

[38] Peterson, K. A. Systematically Convergent Basis Sets with Relativistic Pseudopotentials. I. Correlation Consistent Basis Sets for the Post-d group 13-15 Elements. J. Chem. Phys. 2003, 119, 1109911112.

[39] Fukui, K. The Path of Chemical Reactions - The IRC Approach. Acc. Chem. Res. 1981, 14, 363-368.

[40] Hratchian, H. P.; Schlegel, H. B. Accurate Reaction Paths using a Hessian Based Predictor-Corrector Integrator. J. Chem. Phys. 2004, 120, 9918-9924. 
[41] Hratchian, H. P.; Schlegel, H. B. Theory and Applications of Computational Chemistry: The First 40 Years, Ed. Dykstra, C. E.; Frenking, G.; Kim, K. S.; Scuseria, G.; Elsevier, Amsterdam, 2005, pp. 195249.

[42] Hratchian, H. P.; Schlegel, H. B. Using Hessian Updating To Increase the Efficiency of a Hessian Based Predictor-Corrector Reaction Path Following Method. J. Chem. Theory and Comput. 2005, 1, 6169.

[43] Weinhold, F.; Carpenter, J. E. The Structure of Small Molecules and Ions; Naaman, R.; Vager, Z. Plenum, 1988, pp. 227-36.

[44] Reed, A. E.; Curtiss, L. A.; Weinhold, F. Intermolecular Interactions from a Natural Bond Orbital, Donor-acceptor Viewpoint. Chem. Rev. 1988, 88, 899-926.

[45] Carpenter, J. E.; Weinhold, F. Analysis of the Geometry of the Hydroxymethyl Radical by the "Different Hybrids for Different Spins" Natural Bond Orbital Procedure. J. Mol. Struct. (Theochem) 1988, 46, 41-62.

[46] Grimme, S.; Antony, J.; Ehrlich, S.; Krieg, H. A Consistent and Accurate Ab initio Parametrization of Density Functional Dispersion Correction (DFT-D) for the 94 Elements H-Pu. J. Chem. Phys. 2010, 132,154104

[47] Contreras-García, J.; Johnson, E. R.; Keinan, S.; Chaudret, R.; Piquemal, J.; Beratan, D. N.; Yang, W. NCIPLOT: A Program for Plotting Noncovalent Interaction Regions. J. Chem. Theory Comput. 2011, 7, 625- 632.

[48] Szabó, I.; Czakó, G. Revealing a double-inversion mechanism for the $\mathrm{F}^{-}+\mathrm{CH}_{3} \mathrm{Cl}_{\mathrm{N}} 2$ reaction. Nat. Com. 2015, 6, 5972.

[49] Zheng, C.; Xia, Z.-L.; You, S.-L.. Unified Mechanistic Understandings of Pictet-Spengler Reactions Chem. 2018, 4, 1952-1966. 
